\title{
Az integrált viselkedéses modell alkalmazása az egészségmagatartás befolyásolására I.
}

\author{
Kiss Marietta - Fehér András - Kontor Enikő \\ Debreceni Egyetem
}

\begin{abstract}
A TANULMÁNY CÉLJA
Számos elmélet található a hazai és nemzetközi szakirodalomban, melyek az egészségmagatartás különböző formáit igyekeznek magyarázni. Ezek egyik körét jelentik a társas-kognitív magatartási elméletek, melyek sikeresen jeleztek elöre és magyaráztak számos magatartást, köztük sokféle egészségmagatartás-formát, illetve számos eredményes, viselkedésváltozást célzó beavatkozás alapjául is szolgáltak. A több társas-kognitív magatartási modell integrálásával létrejött integrált viselkedéses modell hasonlóan sikeresnek bizonyult bizonyos egészségmagatartás-formák magyarázatában, előrejelzésében és a viselkedésváltozást célzó programok megalapozásában is, mégsem terjedt el széles körben a használata, különösen a hazai szakirodalomban. Kétrészes tanulmányunk célja ezért elméleti áttekintést adni a modell felépítéséről és használatának módjáról, ezzel segítve a jövőbeli alkalmazását a hazai empirikus kutatásokban az egészségmagatartás (és esetleg más magatartásformák) területén.
\end{abstract}

\section{ALKALMAZOTT MÓDSZERTAN}

Tanulmányainkban szekunder kutatás segítségével tártuk fel és mutattuk be az integrált viselkedéses modell eredetével, felépítésével, valamint gyakorlati alkalmazásával kapcsolatos hazai, illetve nemzetközi szakirodalmat.

\section{LEGFONTOSABB EREDMÉNYEK}

Jelen tanulmány az integrált viselkedéses modell elméleti alapjait és felépítését taglalja, míg a második rész a modell gyakorlati alkalmazásának kérdéseit mutatja be. Mivel a magyar szakirodalomból a modell szinte teljesen hiányzik, a kapcsolódó elméleti és gyakorlati tapasztalatok szisztematikus áttekintése hiánypótlónak tekinthető.

\section{GYAKORLATI JAVASLATOK}

Az integrált viselkedéses modell a szakirodalomban fellelhető és a tanulmányban bemutatott módszertan alapján, a korábbi példák analógiájára sikerrel alkalmazható olyan egészségmagatartás-formák esetén, melyeket eddig a szakirodalom más elméletekkel próbált magyarázni.

Kulcsszavak: integrált viselkedéses modell, szándékolt cselekvés elmélete, tervezett cselekvés elmélete, egészségmagatartás

Köszönetnyilvánitás: A publikáció elkészítését az EFOP-3.6.2-16-2017-00003 számú projekt támogatta. A projekt az Európai Unió támogatásával, az Európai Szociális Alap társfinanszírozásával valósult meg.

DOI: 10.15170/MM.2020.54.KSZ.II.05 


\section{BEVEZETÉS INTRODUCTION}

Számos elmélettel, modellel találkozhatunk a hazai és nemzetközi szakirodalomban, melyek a különböző magatartásformákat, köztük az egészségmagatartás különböző elemeit igyekeznek magyarázni. Ezek egyik népszerü körét jelentik a társas-kognitív magatartási modellek (Teleki \& Tiringer 2017), melyek elméleti keretet nyújtanak ahhoz, hogy a viselkedés mögött meghúzódó hiedelmeket azonosíthassuk, amelyek aztán viselkedésváltozást célzó beavatkozások alapjául szolgálhatnak (Abraham et al. 1998).

A szakirodalomban talán a legelterjedtebb társas-kognitív magatartási modellek a szándékos cselekvés elmélete (Theory of Reasoned Action - TRA) (Ajzen \& Fishbein 1980) és a tervezett cselekvés elmélete (Theory of Planned Behavior - TPB) (Ajzen 1991), melyek egyaránt azt feltételezik, hogy a magatartás (behavior) legjobb elörejelzője a viselkedéses szándék (behavioral intention), a viselkedéses szándékot pedig elsősorban a magatartással szembeni attitüd (attitude), a szubjektív társadalmi normák (subjective norms), illetve a TPB szerint ezek mellett még az észlelt magatartásirányítás (perceived behavioral control) befolyásolja. A két modell eltéréseit a következő fejezet tárgyalja.

A TRA és a TPB sikeresen elöre jelzett és magyarázott olyan egészségmagatartás-formákat és viselkedéses szándékokat, mint a dohányzás, az alkoholfogyasztás, az egészségügyi szolgáltatá- sok igénybe vétele, a napozás káros hatásai elleni védelem, a szoptatás, a testmozgás, a droghasználat, a HIV és egyéb nemi betegségek megelőzése, a fogamzásgátló használata, a mammográfia igénybe vétele, illetve a bukósisak és a biztonsági öv használata (Albarracín et al. 1997, 2003, 2005, Blue 1995, Bogart et al. 2000, Craig et al. 1996, Godin \& Kok 1996, Montaño et al. 1997, Montaño \& Taplin 1991, Morrison et al. 1998, Steen et al. 1998, Trafimow 1996). Emellett több példát lehet találni arra is, hogy a TRA és TPB modellkonstrukcióira épülő, viselkedésváltoztatást célzó beavatkozások sikeresen érték el a kívánt magatartásváltozást (Albarracín et al. 2003, 2005, Kalichman 2007).

További, a szakirodalomban gyakran előforduló társas-kognitív magatartáselméletek a társas-kognitív elmélet (Social Cognitive Theory - SCT) (Bandura 1994, 2006), az interperszonális viselkedés elmélete (Theory of Interpersonal Behavior - TIB) (Triandis 1980) és az egészséghiedelem modell (Health Belief Model - HBM) (Becker 1974, Janz \& Becker 1984).

E modellek - számos eltérő vonásuk mellett igen sok hasonlóságot mutatnak, és ezekre építve több kísérlet is történt a TRA és a TPB kiterjesztésével, adaptálásával egy integrált modell létrehozására (Heimlich \& Ardoin 2008). Az ezek eredményeképpen létrejött modelleket eltérö elnevezésekkel lehet a nemzetközi szakirodalomban fellelni (1. táblázat). Jelen tanulmányban az integrált modellekre együttesen a szakirodalomban leggyakrabban használt integrált viselkedéses modellként (IBM) hivatkozunk.

\section{1. táblázat: Az integrált viselkedéses modell elnevezései a szakirodalomban Table 1. Appellations of Integrated Behavioral Model in the literature}

\begin{tabular}{|l|l|}
\hline Szerző(k) & EInevezés \\
\hline $\begin{array}{l}\text { Braun (2012), Kasprzyk et al. (1998), Kasprzyk } \\
\text { \& Montaño (2007), Montaño \& Kasprzyk (2008), } \\
\text { Szabó (2016) }\end{array}$ & Integrated Behavioral Model \\
\hline $\begin{array}{l}\text { Fishbein et al. (2002), Fishbein \& Cappella (2006), } \\
\text { Fishbein \& Yzer (2003), Rhodes } \text { et al. (2007) }\end{array}$ & Integrative Model of Behavioral Prediction \\
\hline $\begin{array}{l}\text { Fishbein } \text { et al. (2002), Fishbein \& Yzer (2003), } \\
\text { Kasprzyk et al. (1998), Kenski et al. (2001) }\end{array}$ & Integrated Theoretical Model \\
\hline Danter (2005), Heimlich \& Ardoin (2008) & Integrated Model of Behavioral Prediction \\
\hline Fishbein (2000) & Integrated Model \\
\hline von Haeften et al. (2001) & Integrative Behavioral Prediction Model \\
\hline von Haeften \& Kenski (2001) & Integrated Theoretical Behavior Prediction Model \\
\hline
\end{tabular}

Forrás: saját összeállitás 
Az IBM alkalmazása mindeddig nem terjedt el széles körben sem a nemzetközi, sem a hazai szakirodalomban, egyik formájában sem. Ez talán viszszavezethető arra, hogy - bár a viselkedés elméleti szintü vizsgálatára a TRA-hoz és TPB-hez hasonlóan kiválóan alkalmas - komplexitása megnehezítheti az alkalmazását (Heimlich \& Ardoin 2008). Az eddig megjelent publikációk szinte kizárólag az egészségmagatartás valamely konkrét (és nem túl sok) aspektusát vizsgálták a modell segítségével, holott az alkotóelemeinek általános jellege miatt általánosítható lenne a magatartásformák egy szélesebb körére (Fishbein 2000, Fishbein \& Yzer 2003), azaz minden olyan magatartás vizsgálatára használható lenne, amely esetén a modell előzményeit, leginkább a TRA-t és a TPB-t sikerrel alkalmazták.

Eddig a témában született empirikus kutatások döntő többsége (Fishbein et al. 2002, Kasprzyk et al. 1998, Kasprzyk \& Montaño 2007, Kenski et al. 2001, Montaño \& Kasprzyk 2008, Rhodes et al. 2007, von Haeften et al. 2001, von Haeften \& Kenski 2001) az IBM-et az óvszerhasználati szándékot befolyásoló tényezők feltárására használta, a HIV és egyéb nemi betegségek megelőzésére szolgáló magatartásváltozást célzó programok kidolgozását elősegítendő. E programok jelentős magatartásváltozást értek el (CDC 1996, Kamb et al. 1996, 1998, Rhodes et al. 2007, Wolitski et al. 1999), alátámasztva a modell gyakorlati használhatóságát, hasznosságát. Emellett egy kutatás (Fishbein \& Cappella 2006) dohányzásellenes kommunikáció megalapozásához alkalmazta a modellt, egy a mértéktelen ivást befolyásoló tényezőket vizsgálta a segítségével (Braun 2012), egy pedig (Danter 2005) azt, hogy mi befolyásolja, hogy a tanárok mennyire hajlandóak alkalmazni a későbbiekben egy workshopon tanultakat. A szerzők tudomása szerint egyetlen hazai empirikus kutatás (Szabó 2016) használta eddig a modellt, az egészséges életmód követését befolyásoló tényezők feltárására.

Jelen kétrészes tanulmány célja ezért áttekintést adni az integrált viselkedéses modell felépítéséröl és használatának módjáról, illetve az IBM megértéséhez nélkülözhetetlen, a modell alapját képező egyéb társas-kognitív magatartási modellek alapjairól, ezzel segítve az IBM jövőbeli alkalmazását a hazai empirikus kutatásokban az egészségmagatartás (és esetleg más magatartásformák) területén.

\section{AZ INTEGRÁLT VISELKEDÉSES MODELL FELÉPÍTÉSE STRUCTURE OF THE INTEGRA- TED BEHAVIORAL MODEL}

Az IBM némileg eltérő formában, felépítéssel szerepel a különböző empirikus kutatásokban, még nem kristályosodott ki egy mindenhol, mindenkor érvényes végső modell. De talán ilyet hasztalan is keresni, hiszen ahogy Kasprzyk és Montaño (2007) megjegyzi, az IBM kérdőívét a szóban forgó populáció és magatartásforma figyelembe vételével kell kialakítani, ami nyilvánvalóan némileg eltérő modellekhez vezet, még ha az alapvető összefüggések általában érvényesek is.

A következőkben a különböző tanulmányokban alkalmazott IBM modellek közös elemeit ismertetjük, majd utalunk a szakirodalomban fellelhetö esetleges eltérésekre is. Különös figyelmet fordítunk a Montaño és Kasprzyk (2008) tanulmányában szereplő modellre, mely a szakirodalomban megtalálható modellek közül a legrészletesebben értelmezi az modellkonstrukciókat ${ }^{1}$.

A TRA és a TPB feltételezi, hogy a viselkedés legfontosabb meghatározója a viselkedéses szándék (Fishbein et al. 2002, Fishbein \& Yzer 2003, Montaño \& Kasprzyk 2008), mely összefüggés az IBM-ben is központi szerepet tölt be. A viselkedéses szándék annak a szubjektív valószínüsége, hogy az egyén követni fogja (vagy megpróbálja követni) a magatartást (Fishbein et al. 2002). Az IBM három fö, minden tanulmányban szereplő konstrukciója, mely meghatározza a viselkedéses szándékot, az adott magatartással szembeni attitüd (attitude), a magatartással kapcsolatos társadalmi norma (subjective norm), valamint az énhatékonyság (self-efficacy) vagy észlelt magatartásirányítás (perceived behavioral control). Ezek közvetlenül levezethetők a bevezetőben említett öt modellböl, és alkotóelemeik sok tekintetben hasonlóak, ám azok konceptualizálása és operacionalizálása eltér egymástól.

A fent említett elméletek a magatartás legfontosabb meghatározójának a viselkedés észlelt kimenetét tekintik (Kasprzyk et al. 1998). A SCT szerint az ösztönzi egy adott viselkedésre az egyént, ha a pozitív kimenetek felülmúlják a negatívakat. Ehhez hasonlóan a HBM szerint nagyobb annak a valószínüsége, hogy egy egyén egy adott viselkedést mutat, ha annak észlelt elönyei felülmúlják a visel-

1 E modellt alkalmazta disszertációjában - a modellkonstrukciók konkrét mérésének némi eltérésével Braun (2012) és Szabó (2016) is. 
kedés megvalósítása előtt álló korlátokat (Fishbein et al. 2002, Fishbein \& Yzer 2003, Kasprzyk et al. 1998). A TRA, a TPB és a TIB egyaránt tartalmazza a magatartás lehetséges következményeivel kapcsolatos hiedelmeket és a magatartás kimeneteinek értékelését, az előbbit az utóbbival súlyozva (Fishbein et al. 2002, Kasprzyk et al. 1998), melyek együttesen meghatározzák a magatartás irányában mutatott attitüdöt. Az attitüd pedig nem más, mint az egyén átfogó pozitív vagy negatív érzése azzal kapcsolatban, hogy az adott magatartást kövesse (Fishbein et al. 2002, Fishbein \& Yzer 2003). Minél inkább hisz az egyén abban, hogy a magatartás pozitív kimenettel jár (vagy megelőz bizonyos negatív kimeneteket), annál kedvezőbb lesz az attitüdje a magatartás irányában (Fishbein et al. 2002).

A második fontos koncepció, mely az öt elmélet majdnem mindegyikében szerepel, a társadalmi támogatás (vagy normatív komponens). A TRA, a TPB és a TIB a magatartás észlelt társadalmi támogatását tartalmazza, a SCT pedig a magatartás észlelt társadalmi kimeneteit. A HBM eredetileg nem foglalta magába a társadalmi támogatást, de a későbbi verzióiban már ezt is beemelték a modellbe (Kasprzyk et al. 1998). A TRA és a TPB az attitűdhöz hasonlóan a viselkedéses szándékot közvetlenül befolyásoló szubjektív norma mögöttes tényezőit is meghatározza, melyek nem mások, mint az egyén normatív hiedelmei arról, hogy a számára fontos referenciaszemélyek támogatják-e vagy sem az adott magatartást, súlyozva az egyén azon motivációjával, hogy megfeleljen e referenciaszemélyeknek. Ha az egyén úgy hiszi, hogy a számára fontos referenciaszemélyek szerint követnie kellene (nem kellene követnie) egy bizonyos magatartást, és szeretne megfelelni e referenciaszemélyek elvárásainak, pozitív (negatív) szubjektív normával fog rendelkezni, és nagyobb (kisebb) valószínüséggel követi az adott magatartást (Fishbein et al. 2002, Montaño \& Kasprzyk 2008). Ha viszont a számára fontos referenciaszemélyeknek nem akar megfelelni, semleges szubjektív normát fog mutatni (Montaño \& Kasprzyk 2008).

A harmadik koncepció, mely több elméletben is megjelenik, a környezeti vagy szituációs feltételek hatása a magatartásra. E koncepció különböző modellekben (SCT, TIB, TPB) megjelenő koncep- tualizációja nagyon hasonló, viszont az operacionalizálása jelentősen eltér (Kasprzyk et al. 1998). A SCT a tényezőt énhatékonyságnak nevezi ${ }^{2}$, ami az egyén értékelése arra vonatkozóan, hogy menynyire képes az adott magatartást követni változó körülmények vagy korlátok között (Fishbein et al. 2002, Fishbein \& Yzer 2003, Kasprzyk et al. 1998). A TIB terminológiája szerint e tényezők az elösegítő feltételek, melyek a környezet vagy az egyén olyan jellemzői, amelyek megkönnyítik vagy megnehezítik az adott magatartás követését (Kasprzyk et al. 1998). A TPB a viselkedéses szándék harmadik meghatározó tényezőjeként az egyén adott magatartás fölötti kontrolljának észlelt szintjét tartalmazza, ez az a tényező, amellyel a TPB több a TRA-nál, ez alapján azt mondhatjuk, hogy a TRA a TPB kiterjesztésének tekinthető (Montaño \& Kasprzyk 2008), ahogy az az 1. ábrán látható. ${ }^{3}$ Ez a tényező olyan esetekben lehet fontos, amikor az egyén nem rendelkezik teljes körü akaratlagos irányítással a magatartás követése fölött, szemben a TRA feltételezésével (Montaño \& Kasprzyk 2008). Hasonlóan az előző két direkt befolyásoló tényezőhöz, a TPB meghatározza az észlelt magatartásirányítás mögötti indirekt befolyással bíró tényezőket is, melyek a magatartáshoz szükséges erőforrások és a magatartással szembeni akadályok meglétével kapcsolatos kontrollhiedelmek, a magatartást elösegítő vagy akadályozó egyes erőforrások és akadályok észlelt erősségével vagy hatásával súlyozva (Kasprzyk et al. 1998, Montaño \& Kasprzyk 2008).

2 Ezt a megközelítést alkalmazza Rhodes et al. (2007), illetve az észlelt magatartásirányítás mellett az énhatékonyságot is beépítette az IBM-be Braun (2012), Kasprzyk és Montaño (2007), Montaño és Kasprzyk (2008) és Szabó (2016).

3 Megjegyzendő, hogy az empirikus tanulmányok egy részének eredményei szerint a magatartás észlelt kontrollja az indirekt (viselkedéses szándékon keresztüli) hatás mellett direkt módon is befolyásolja a viselkedést (lásd pl. Godin \& Kok 1996). 


\section{1. ábra: Az integrált viselkedéses modell (IBM) alapját képző szándékolt cselekvés elmélete (TRA) és tervezett viselkedés elmélete (TPB) \\ Figure 1. Theory of Reasoned Action (TRA) and Theory of Planned Behaviour (TPB) underlying Integrated Behavioral Model}

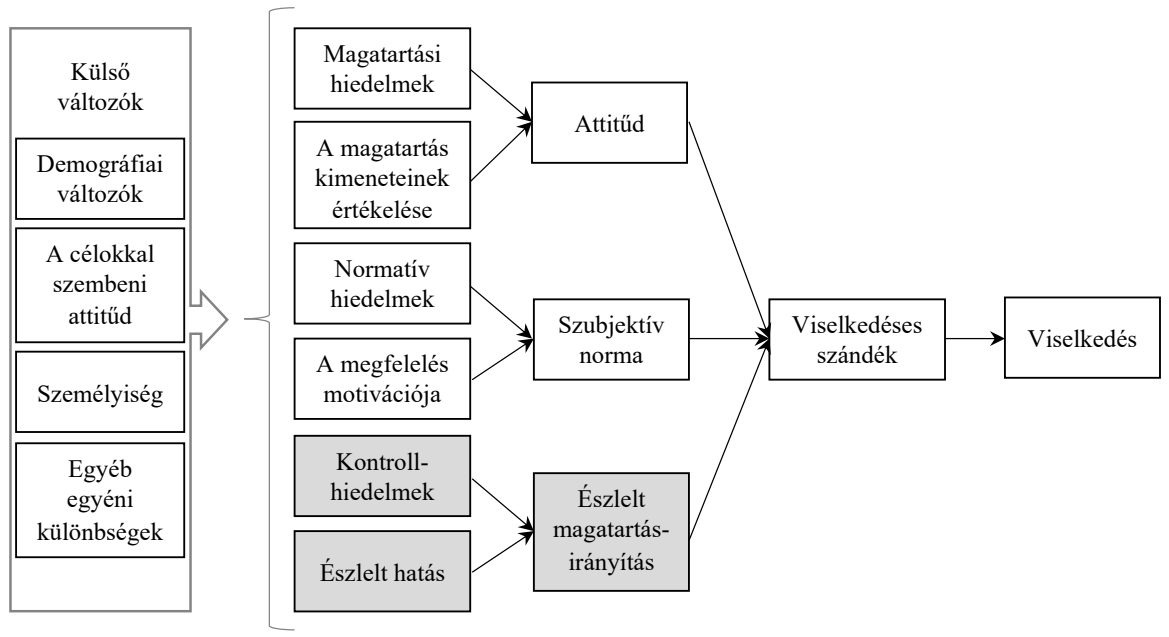

Megjegyzés: A fehér téglalapok a TRA részei, mig a teljes ábra (a fehér és a szürke téglalapok együtt) a TPB-t mutatja.

Forrás: Montaño \& Kasprzyk (2008)

Az egyéb faktorok, úgymint a demográfiai, kulturális tényezők, a célokkal szembeni attitüdök (pl. sztereotípiák, stigmák), a személyiség, hangulat és érzelmek, egyéb egyéni különbségek (pl. észlelt kockázatok), valamint a média és egyéb beavatkozások a modell feltételezése szerint a modellkonstrukciókon keresztül, indirekt módon hatnak, közvetlenül nem befolyásolják egy adott magatartás folytatásának valószínűségét, ezért külső vagy háttértényezőknek is nevezhetjük azokat (Fishbein 2000, Fishbein et al. 2002, Fishbein \& Yzer 2003, Fishbein \& Cappella 2006, Montaño \& Kasprzyk 2008).

A fent részletezett közös elemeken kívül néhány kutatás egyéb, specifikus konstrukciókat is szerepeltet a modellben. Kenski et al. (2001), Rhodes et al. (2007), von Haeften és Kenski (2001) valamint von Haeften et al. (2001) modelljei például tartalmazzák a partner normát (partner norm) mint a viselkedéses szándék direkt befolyásolóját. Bár ez a tényező külön nem szerepel sem a TRA-ban, sem a TPB-ben, korábbi kutatások azt sugallták, hogy speciálisan az említett tanulmányokban vizsgált magatartás (óvszerhasználat) esetén az egyén azon hiedelme, hogy a partnere úgy véli, hogy mindig használnia kellene, vagy éppen nem mindig kellene használnia óvszert, hozzájárul a viselkedéses szándék elörejelzéséhez a szubjektív normán túl.

Kasprzyk et al. (1998) szintén speciálisan az óvszerhasználatot befolyásoló tényezők vizsgálatánál a három, TPB-ből származó direkt befolyásoló tényezö mellett két újabb, közvetlen befolyással bíró tényezőt emelt be a modellbe: az alternatív stratégiákat (alternative strategies) és a kritikus eseményeket (critical events). Érvelésük szerint ugyanis bár egy személy rendelkezhet pozitív attitủddel az adott magatartással szemben, mégsem fogja azt követni, mert esetleg egy másik magatartást (alternatív stratégiát) szándékozik folytatni, amellyel megvédheti magát a negatív következményektöl. A kritikus események olyan érzelmileg jelentös események, melyek függetlenek a kognitív alapú attitüd, társadalmi norma és észlelt magatartásirányítás konstrukcióitól. Például lehetnek valakinek pozitív hiedelmei és attitüdje egy adott magatartás iránt, mégsem feltétlenül fog e szerint cselekedni, ha egyetlen nagyon negatív tapasztalatot szerzett vele kapcsolatban. 


\section{A MONTAÑO ÉS KASPRZYK (2008)-FÉLE INTEGRÁLT VISEL- KEDÉSES MODELL \\ INTEGRATED BEHAVIORAL MODEL BY MONTAÑO AND KASPRZYK (2008)}

Az IBM Montaño és Kasprzyk (2008) által kidolgozott változata (2. ábra) a TRA/TPB által azonosított tényezők mellett négy másikat is tartalmaz melyek közvetlenül a viselkedésre (és nem a viselkedéses szándékra) hatnak (Jaccard et al. 2002). Ezek közül az első három azt határozza meg, hogy a viselkedéses szándék hatására kialakul-e a magatartás. Elöször is, még ha az egyén erős szándékkal is rendelkezik egy adott magatartás irányában, szüksége van ismeretekre és képességekre (knowledge and skills) a magatartás követéséhez (Montaño \& Kasprzyk 2008). Emellett ahogy a TIB is kiemeli, fontos az is, hogy egyáltalán ne legyen, vagy csak kevés környezeti korlát (environmental constraints) legyen, amelyek a magatartást megnehezítik vagy lehetetlenné teszik (Triandis 1980). ${ }^{5}$ Harmadrészt a HBM alapján a magatartásnak kiemelkedőnek, fontosnak (salient) kell lennie a személy számára (Becker 1974). Végül ahogy a TIB is tartalmazza, a magatartás rendszeres gyakorlásával az szokássá (habit) válik, ekkor pedig a szándék kevésbé lesz fontos a viselkedés meghatározásában (Triandis 1980).

\section{2. ábra: Az integrált viselkedéses modell (IBM)}

Figure 2. Integrated Behavioral Model (IBM)

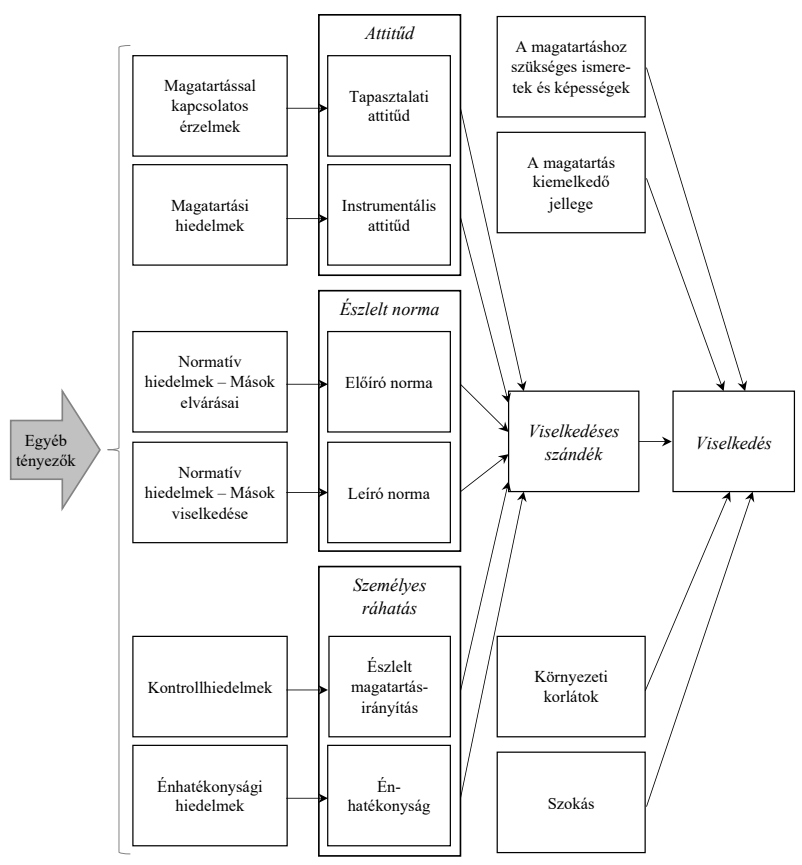

Forrás: Montaño \& Kasprzyk (2008)

4 Bár Braun (2012) és Szabó (2016) is e modellt veszi alapul, a viselkedéses szándékon kívüli négy, magatartásra közvetlenül ható tényezőt Szabó (2016) nem vizsgálja empirikusan, Braun (2012) pedig csak a környezeti korlátokat emeli be közülük modelljébe.

5 E két tényező megjelenik Fishbein (2000), Fishbein et al. (2002), Fishbein és Yzer (2003) valamint Fishbein és Cappella (2006) IBM-jében is. 
A TRA/TPB-hez hasonlóan a viselkedés egyik direkt befolyásolója Montaño és Kasprzyk (2008) IBM-jében is az attitüd, azonban a szerzők kétféle attitüdöt különböztetnek meg, a tapasztalati (experiential) és az instrumentális (instrumental) attitüdöt. A tapasztalati vagy affektív attitüd (affect) ${ }^{6}$ a személy érzelmi válasza az adott magatartás követésének gondolatára (Fishbein 2007). Azok, akik erőteljes pozitív (negatív) érzelmekkel viseltetnek a magatartás irányában, nagyobb (kisebb) valószínüséggel követik majd. Az affektív attitüd egy fontos komponense a múltbeli viselkedés, ugyanis ha a múltban az egyén pozitív tapasztalatokat szerzett azáltal, hogy az adott viselkedést folytatta, nagyobb valószínúséggel fogja azt a jövőben is folytatni. Az instrumentális attitüd ezzel szemben kognitív alapú, és a magatartás kimeneteire vonatkozó hiedelmek határozzák meg, csakúgy, mint a TRA/TPB-ben (Braun 2012).

A szándék második direkt befolyásolója Montaño és Kasprzyk (2008) modelljében is az észlelt norma, amely a társadalmi nyomást tükrözi arra vonatkozóan, hogy egy adott magatartást kell, vagy nem kell követni. Fishbein (2007) szerint a szubjektív norma, ahogy azt a TRA/TPB elöíró (injunctive) felfogásban definiálja (normatív hiedelmek arra vonatkozóan, hogy mások szerint mit kellene tennie az egyénnek, illetve a nekik való megfelelés motivációja) nem feltétlenül ragadja meg a normatív befolyás egészét. Fontos részét képezi ugyanis a normatív befolyásnak az egyén észlelése arra vonatkozóan is, hogy mások az egyén társadalmi és személyes kapcsolati hálójában mit tesznek, ez pedig a leíró (descriptive) norma (Montaño \& Kasprzyk 2008). Annál nagyobb a valószínüsége tehát, hogy az egyén egy adott magatartást mutat, minél inkább úgy hiszi, hogy a referenciaszemélyek szerint követnie kellene azt, minél inkább meg akar felelni nekik és a referenciaszemélyek minél inkább maguk is folytatják a magatartást (Braun 2012, Fishbein \& Cappella 2006).

A harmadik direkt befolyásoló tényező Montaño és Kasprzyk (2008) modelljében a SCT (Bandura 2006) által javasolt személyes ráhatás (personal agency), azaz az egyén befolyása a saját múködésére és a környezetének eseményeire. A személyes ráhatás két konstrukcióból épül fel, az énhatékonyságból és az észlelt magatartásirányításból. Az utóbbi nem más, mint az egyén észlelt kontrollja a magatartás fölött, amelyet az egyén azon észlelése határoz meg, hogy a különböző környezeti faktorok milyen mértékben könnyítik vagy nehezítik meg a magatartás követését. Az énhatékonyság pedig annak a mértéke, hogy az egyén mennyire bízik abban, hogy képes a magatartást követni a különböző akadályok és kihívások tükrében (Montaño \& Kasprzyk 2008). Az észlelt magatartásirányítást inkább külső, míg az énhatékonyságot inkább belső kontrollnak tekinthetjük (Braun 2012).

Hasonlóan a többi kutatásban alkalmazott IBMhez, az előbbi direkt befolyásoló tényezők mögött Montaño és Kasprzyk (2008) modelljében is hiedelmek húzódnak meg. Ahogy az a 2. ábrán látszik, az instrumentális attitüd a magatartás kimenetével kapcsolatos hiedelmek függvénye. Minél erősebb az egyén hite abban, hogy a magatartás pozitív kimenetü lesz, annál kedvezőbb lesz az attitüdje iránta. Azonban az attitüd TRA/TPB-ben szereplő indirekt mérésével ellentétben itt a kimenetek értékelése nem része a modellnek, ugyanis több kutatás is feltárta, hogy a különböző egészségmagatartások esetén az emberek értékelésének általában kicsi a varianciája (Fishbein et al. 2001, Kasprzyk \& Montaño 2007, von Haeften et al. 2001, von Haeften \& Kenski 2001). Ugyanakkor ha az ellenkezőjére derül fény, ezt az elemet is érdemes a modellbe foglalni.

Az észlelt normák tényezője a TRA/TPB konstrukciójához hasonlóan a normatív hiedelmek függvénye. Minél erősebbek az egyén hiedelmei, hogy bizonyos személyek vagy csoportok úgy vélik, követnie kellene az adott magatartást, vagy ezek az egyének vagy csoportok követik is azt, annál erősebb az egyén által észlelt társadalmi nyomás, hogy ö is kövesse. A TRA/TPB-vel ellentétben az egyéneknek vagy csoportoknak való megfelelés motivációja nem szerepel a modellben, ugyanis az - hasonlóan a magatartás kimeneteinek értékeléséhez - gyakran kis varianciát mutat. Ellenkezö esetben viszont mérni kell a megfelelés motivációját is (Montaño \& Kasprzyk 2008).

A személyes ráhatás egyik része az észlelt magatartásirányítás, mely a TPB-nek megfelelően a különböző elősegítő vagy korlátozó feltételek megjelenésének valószínúségére vonatkozó kontrollhiedelmek függvénye, a feltételeknek a magatartást megkönnyítő vagy megnehezítő észlelt hatásával súlyozva. Végül minél erősebb egy személy hiedelme, hogy az adott magatartást tudja folytatni a különböző korlátok ellenére, annál nagyobb lesz az énhatékonysága ${ }^{7}$ a magatartás követésével kapcsolatban (Montaño \& Kasprzyk 2008).

\footnotetext{
${ }^{6}$ Az attitüd és az affektív attitüd elkülönítése már Kasprzyk és Montaño (2007) tanulmányában is megjelent.

7 Az észlelt magatartásirányítás és az énhatékonyság elkülönítése már Kasprzyk és Montaño (2007) tanulmányában is megjelent.
} 
A többi IBM-hez hasonlóan ez a modell is magába foglal egyéb demográfiai, személyiségbeli, attitüdbeli és egyéni különbségekre vonatkozó változókat, de ezek itt is csak közvetetten, az elméleti konstrukciókon keresztül hatnak, ezért külső változókként foghatjuk fel azokat. Szerepük az, hogy segítségükkel szegmentálható a népesség, ha a szegmensek hiedelmeiben világos különbségek vannak, és szegmensenként eltérö beavatkozási módokat lehet kidolgozni a számukra (Montaño \& Kasprzyk 2008).

\section{HIVATKOZÁSOK REFERENCES}

Abraham, C., Sheeran, P. and Orbel, S. (1998), "Can Social Cognitive Models Contribute to the Effectiveness of HIV-Preventive Behavioral Interventions? A Brief Review of the Literature and a Reply to Joffe $(1996$; 1997) and FifeSchaw (1997)", British Journal of Medical Psychology, 71(3), 297-310 DOI: 10.1111/j.20448341.1998.tb00993.x

Ajzen, I. (1991), "The Theory of Planned Behaviour", Organizational Behavior and Human Decision Processes, 50(2), 179-211 DOI: 10.1016/0749-5978(91)90020-T

Ajzen, I. and Fishbein, M. (1980), Understanding Attitudes and Predicting Social Behaviour, Prentice Hall, Englewood-Cliffs, NJ.

Albarracín, D., Fishbein, M. and Goldestein de Muchinik, E. (1997), "Seeking Social Support in Old Age as Reasoned Action: Structural and Volitional Determinants in a Middle-Aged Sample of Argentinean Women", Journal of Applied Social Psychology, 27(6), 463-476 DOI: 10.1111/j.1559-1816.1997.tb00642.x

Albarracín, D., McNatt, P. S., Klein, C. T., Ho, R. M., Mitchell, A. L. and Kumkale, G. T. (2003), "Persuasive Communications to Change Actions: An Analysis of Behavioral and Cognitive Impact in HIV Prevention", Health Psychology, 22(2), 166-177 DOI: 10.1037/02786133.22.2.166

Albarracín, D., Gillette, J. C., Earl, A. N., Glasman, L. R., Durantini, M. R. and Ho, M. H. (2005), "A Test of Major Assumptions About Behavior Change: A Comprehensive Look at the Effects of Passive and Active HIV-Prevention Interventions ince the Beginning of the Epidemic", Psychological Bulletin, 131(6), 856-897 DOI: 10.1037/0033-2909.131.6.856

Bandura, A. (1994), "Social Cognitive Theory and Exercise of Control over HIV Infection", in: DiClemente, R. and Peterson, J. L. (eds.), Preventing AIDS: Theories and Methods of Behavioral Interventions, Plenum Press, New York, 25-29 DOI: 10.1007/978-1-4899-1193-3_3

Bandura, A. (2006), "Toward a Psychology of Human Agency", Perspectives on Psychological Science, 1(2), 164-180 DOI: 10.1111/j.17456916.2006.00011.x

Becker, M. H. (1974), “The Health Belief Model and Personal Health Behaviour", Health Education Monographs", 2(4), 409-419 DOI: 


\subsection{7/109019817400200407}

Blue, C. L. (1995), "The Predictive Capacity of the Theory of Reasoned Action and the Theory of Planned Behavior in Exercise Research: An Integrated Literature Review", Research in Nursing and Health, 18(2), 105-121 DOI: 10.1002/nur.4770180205

Bogart, L. M., Cecil, H. and Pinkerton, S. D. (2000), "Intentions to Use the Female Condom among African American Adults", Journal of Applied Social Psychology, 30(9), 1923-1953 DOI: 10.1111/j.1559-1816.2000.tb02475.x

Braun, R. E. (2012), Using the Integrated Behavioral Model to Predict Binge Drinking Among College Students, Doctoral (PhD) Dissertation, The University of Toledo

CDC (1996), "Community-level Prevention of Human Immunodeficiency Virus Infection among High-Risk Populations: The AIDS Community Demonstration Projects." Morbidity and Mortality Weekly Report - Recommendations and Reports, 45(RR-6), U.S. Department of Health and Human Services, Public Health Service, Centers for Disease Control and Prevention (CDC), Atlanta, GA.

Craig, S., Goldberg, J. and Dietz, W. H. (1996), "Psychosocial Correlates of Physical Activity among Fifth and Eighth Graders", Preventive Medicine, 25(5), 506-513 DOI: 10.1006/ pmed.1996.0083Get

Danter, E. H. (2005), The Intention-Behavior Gap: To What Degree Does Fishbein's Integrated Model of Behavioral Prediction Predict Whether Teachers Implement Material Learned in a Professional Development Workshop?, Doctoral $(\mathrm{PhD})$ Dissertation, The Ohio State University

Fishbein, M. (2000), "The Role of Theory in HIV Prevention", AIDS Care, 12(3), 273-278 DOI: 10.1080/09540120050042918

Fishbein, M. (2007), “A Reasoned Action Approach: Some Issues, Questions, and Clarifications", in: Ajzen, I., Albarracin, D. and Hornik, R. (eds.): Prediction and Change of Health Behavior: Applying the Reasoned Action Approach, Lawrence Erlbaum, Mahwah, NJ. 281-296

Fishbein, M. and Cappella, J. N. (2006), "The Role of Theory in Developing Effective Health Communications", Journal of Communication, 56 S1, S1-S17 DOI: 10.1111/j.14602466.2006.00280.x

Fishbein, M., Cappella, J., Hornik, R., Sayeed, S., Yzer, M. and Ahern, R. K. (2002), "The Role of Theory in Developing Effective Antidrug Public Service Announcements", in: Crano, W. D. and
Burgoon, M. (eds.), Mass Media and Drug Prevention: Classic and Contemporary Theories and Research, Lawrence Erlbaum, Mahwah, NJ, 89-117

Fishbein, M., Triandis, H. C., Kanfer, F. H., Becker, M. H., Middlestadt, S. E. and Eichler, A. (2001), "Factors Influencing Behavior and Behavior Change", in: Baum, A., Revenson, T. R. and Singer, J. E. (eds.), Handbook of Health Psychology, Lawrence Erlbaum, Mahwah, NJ, 3-17

Fishbein, M. and Yzer, M. C. (2003), "Using Theory to Design Effective Health Behavior Interventions", Communication Theory, 13(2), 164183 DOI: $10.1111 /$ j.1468-2885.2003.tb00287.x

Godin, G. and Kok, G. (1996), "The Theory of Planned Behavior: A Review of its Applications to Health Related Behaviors", American Journal of Health Promotion, 11(2), 87-98 DOI: 10.4278/0890-1171-11.2.87

Heimlich, J. E. and Ardoin, N. M. (2008), "Understanding Behavior to Understand Behavior Change: A Literature Review", Environmental Education Research, 14(3), 215-237 DOI: 10.1080/13504620802148881

Jaccard, J., Dodge, T. and Dittus, P. (2002), "Parent-Adolescent Communication about Sex and Birth Control: A Conceptual Framework", New Directions in Child and Adolescent Development, (97), 9-42 DOI: 10.1002/cd.48

Janz, N. K. and Becker, M. H. (1984), "The Health Belief Model: A Decade Later", Health Education Quarterly, 11(1), 1-47 DOI: 10.1177/109019818401100101

Kalichman, S. C. (2007), "The Theory of Reasoned Action and Advances in HIV/AIDS", in: Ajzen, I., Albarracín, D. and Hornik, R. (eds.), Prediction and Change of Health Behavior: Applying the Reasoned Action Approach, Erlbaum, Hillsdale, NJ, 265-272

Kamb, M. L., Dillon, B., Fishbein, M., Willis, K. L. and Project RESPECT Study Group (1996), "Quality Assurance of HIV Prevention Counseling in a Multi-Center Randomized Controlled Trial”, Public Health Reports, 111(Suppl. 1), 99-107

Kamb, M., Fishbein, M., Douglas Jr. J. M., Rhodes, F., Rogers, J., Bolan, G., Zenilman, J., Hoxworth, T., Malotte, K., Iatesta, M., Kent, C., Lentz, A., Graziano, S., Byers, R. H. and Petermn, T. A. (1998), "Efficacy of Risk-Reduction Counseling to Prevent Human Immunodeficiency Virus And Sexually Transmitted Diseases", Journal of the American Medical Association, 280(13), 1161-1167 DOI: 10.1001/ jama.280.13.1161 
Kasprzyk, D. and Montaño, D. E. (2007), “Application of an Integrated Behavioral Model to Understand HIV Prevention Behavior of HighRisk Men in Rural Zimbabwe", in: Ajzen, I., Albarracín, D. and Hornik, R. (eds.), Prediction and Change of Health Behavior: Applying the Reasoned Action Approach, Lawrence Erlbaum, Mahwah, NJ, 149-172

Kasprzyk, D., Montaño, D. E. and Fishbein, M. (1998), "Application of an Integrated Behavioral Model to Predict Condom Use: A Prospective Study among High HIV Risk Groups", Journal of Applied Social Psychology, 28(17), 1557-1583 DOI: $10.1111 /$ j.1559-1816.1998. tb01690.x

Kenski, K., Appleyard, J., von Haeften, I., Kasprzyk, D. and Fishbein, M. (2001), "Theoretical Determinants of Condom Use Intentions for Vaginal Sex with a Regular Partner among Male and Female Injecting Drug Users", Psychology, Health \& Medicine, 6(2), 179-190 DOI: $10.1080 / 13548500123751$

Montaño, D. E. and Kasprzyk, D. (2008), "Theory of Reasoned Action, Theory of Planned Behavior, and the Integrated Behavioral Model", in: Glanz, K., Rimer, B. K. and Viswanath, K. (eds.), Health behavior and health education: Theory, research and practice, Jossey-Bass, San Francisco, 67-96

Montaño, D. and Taplin, S. (1991), “A Test of an Expanded Theory of Reasoned Action to Predict Mammography Participation", Social Science and Medicine, 32(6), 733-741 DOI: 10.1016/0277-9536(91)90153-4

Montaño, D., Thompson, B., Taylor, V. M. and Mahloch, J. (1997), "Understanding Mammography Intention and Utilization among Women in an Inner City Public Hospital Clinic", Preventive Medicine, 26(6), 817-824 DOI: 10.1006/ pmed.1997.0215Get

Morrison, D. M., Spencer, M. S. and Gillmore, M. R. (1998), "Beliefs about Substance Use among Pregnant and Parenting Adolescents", Journal of Research on Adolescence, 8(1), 69-95 DOI: 10.1207/s15327795jra0801_4

Rhodes, F., Stein, J. A., Fishbein, M., Goldstein, R. B. and Rotheram-Borus, M. J. (2007), "Using Theory to Understand How Interventions Work: Project RESPECT, Condom Use, and the Integrative Model", AIDS and Behavior, 11(3), 393407 DOI: 10.1007/s10461-007-9208-9

Steen, D. M., Peay, M. Y. and Owen, N. (1998), "Predicting Australian Adolescents' Inten- tions to Minimize Sun Exposure", Psychology and Health, 13(1), 111-119 DOI: 10.1080/08870449808406135

Szabó S. (2016), Egészségorientált táplálkozási szokások és a fogyasztói magatartás kapcsolata, Doktori (PhD) értekezés, Kaposvári Egyetem Gazdaságtudományi Kar

Teleki Sz., Tiringer I. (2017), „Az egészségmagatartás változásának szociális-kognitív folyamatmodellje (HAPA-modell)", Mentálhigiéné és Pszichoszomatika, 18(1), 1-29 DOI: 10.1556/0406.18.2017.001

Trafimow, D. (1996), “The Importance of Attitudes in the Prediction of College Students' Intentions to Drink", Journal of Applied Social Psychology, 26(24), 2167-2188 DOI: 10.1111/j.15591816.1996.tb01794.x

Triandis, H. C. (1980), "Values, Attitudes, and Interpersonal Behavior", in: Howe, H. E. and Page, M. (eds.), Nebraska Symposium on Motivation 1979, No. 27. University of Nebraska Press, Lincoln, 195-259

Von Haeften, I., Fishbein, M., Kasprzyk, D. and Montaño, D. (2001), "Analyzing Data to Obtain Information to Design Targeted Interventions", Psychology, Health \& Medicine, 6(2), 151-164 DOI: 10.1080/13548500125076

Von Haeften, I. and Kenski, K. (2001), "Multi-Partnered Heterosexual's Condom Use for Vaginal Sex With Their Main Partner as a Function of Attitude, Subjective Norm, Partner Norm, Perceived Behavioural Control, and Weighted Control Beliefs", Psychology, Health \& Medicine, 6(2), 165-178 DOI: 10.1080/13548500120035427

Wolitski, R. J., Fishbein, M., Higgins, D. L., Rietmeijer, C., Guenther-Grey, C. A. and Johnson, W. D. (1999), "Community-level HIV Intervention in 5 Cities: Final Outcome Data from the CDC AIDS Community Demonstration Projects", American Journal of Public Health, 89(3), 336-345 DOI: 10.2105/AJPH.89.3.336 
Kiss Marietta $\mathrm{PhD}$, adjunktus kiss.marietta@econ.unideb.hu

Fehér András PhD, adjunktus feher.andras@econ.unideb.hu

Kontor Enikő $\mathrm{PhD}$, adjunktus kontor.eniko@econ.unideb.hu

Debreceni Egyetem Gazdaságtudományi Kar

\section{Application of Integrated Behavioral Model to influence health behavior $\mathrm{I}$.}

\section{THE AIMS OF THE PAPER}

Several theories can be found in domestic and international literature which try to explain different forms of health behavior. One direction of them are social-cognitive theories that have successfully predicted and explained several behaviors, including various health behaviors. Beside this, they have also served as the basis for numerous successful interventions aiming at behavioral changes. Although the Integrated Behavioral Model (IBM) - which was developed by integrating more social-cognitive behavioral models - proved to be similarly successful in explaining and predicting specific health behaviors, and in serving as a basis for programs aiming at behavioral changes, its application has not been widespread yet, especially in the Hungarian literature. The aim of our twopart series is to provide a literature review of the structure and the application methods of the model, assisting its future applications in domestic empirical research in the field of health (and maybe other types of) behaviors.

\section{METHODOLOGY}

In our studies, Hungarian and international literature on the origin, structure, and practical applications of the IBM has been revealed and presented by secondary research.

\section{MOST IMPORTANT RESULTS}

The current study describes the theoretical bases and the structure of IBM, while the second part deals with its practical applications. Since the model is almost totally missing from the Hungarian literature, the systematic review of related theoretical and empirical experiences can be seen as filling the gap.

\section{PRACTICAL RECOMMENDATIONS}

The IBM can be applied successfully for health behaviors that the literature has tried to explain by other theories, based on the methodology and the previous examples found in the literature and presented in the current study.

Keywords: Integrated Behavioral Model, Theory of Reasoned Action, Theory of Planned Behavior, health behavior

Acknowledgement: This publication was supported by the EFOP-3.6.2-16-2017-00003 project. The project is co-financed by the European Union and the European Social Fund. 